\title{
Analysis Concentration of Toxoplasma gondii on Anti-Toxoplasma IgG-IgM Antibody Levels, and the Outcomes of Pregnancy in Mice Balb/c
}

\author{
Tigor Peniel Simanjuntak, Mochammad Hatta ${ }^{2 *}$, Robert H. Sirait ${ }^{3}$, Marni Br Karo ${ }^{4}$, \\ Lenny Irmawaty Sirait ${ }^{4}$, Tetty Rina Aritonang4 ${ }^{4}$ Syahrul Rauf ${ }^{5}$, Ressy Dwiyanti ${ }^{2,6}$
}

\author{
${ }^{1}$ Department of Obstetrics and Gynecology, Faculty of Medicine, Christian University of Indonesia, Jakarta, Indonesia \\ ${ }^{2}$ Molecular Biology and Immunology Laboratory, Faculty of Medicine, Hasanuddin University, Makassar, Indonesia \\ ${ }^{3}$ Department of Anaestesiology, Faculty of Medicine, Christian University of Indonesia, Jakarta, Indonesia \\ ${ }^{4}$ Midwife Program of Medistra Health Higher School, Jakarta, Indonesia \\ ${ }^{5}$ Department of Obstetrics and Gynecology, Faculty of Medicine, Hasanuddin University, Makassar, Indonesia \\ ${ }^{6}$ Department of Medical Microbiology, Faculty of Medicine, Tadulako University, Palu, Indonesia \\ Email: *hattaram@indosat.net.id
}

How to cite this paper: Simanjuntak, T.P., Hatta, M., Sirait, R.H., Karo, M.B., Sirait, L.I., Aritonang, T.R., Rauf, S. and Dwiyanti, R. (2017) Analysis Concentration of Toxoplasma gondii on Anti-Toxoplasma IgG-IgM Antibody Levels, and the Outcomes of Pregnancy in Mice Balb/c. Open Journal of $O b$ stetrics and Gynecology, 7, 281-289. https://doi.org/10.4236/ojog.2017.73030

Received: February 2, 2017

Accepted: March 12, 2017

Published: March 15, 2017

Copyright $\odot 2017$ by authors and Scientific Research Publishing Inc. This work is licensed under the Creative Commons Attribution International License (CC BY 4.0).

http://creativecommons.org/licenses/by/4.0/

\section{Abstract}

Introduction: Toxoplasma gondii is an obligate intracellular protozoan parasite that can infect any warm blood vertebrae, and if first trimester pregnant woman infected, it may cause abortion. The objective is to prove the effect of the Toxoplasma gondii concentration in anti-toxoplasma IgG-IgM antibody levels, and the outcomes of Balb/c mice pregnancies. Materials and Methods: The study was conducted in Balb/c mice with inclusion criteria, and was conditioned pregnant. The pathogen strains of Toxoplasma gondii tachyzoite injected intraperitoneally. The blood samples were taken serially to be tested for anti-toxoplasma IgG-IgM antibody levels. After the mice were injected with tachyzoite, they are assessed every day to observe their body weight, vaginal bleeding, and labor. Anti-toxoplasma IgG-IgM antibody levels examined using qualitative mouse IgG-IgM antibody ELISA KIT. Results: Anti-toxoplasma IgM antibody levels increased significantly after 24 hours of injection tachyzoites in all dose groups, and remained high through day 21. Anti-toxoplasma antibody IgG levels increased significantly after 72 hours post injection and remained elevated until day 21 . The incidence of abortion is $100 \%$ in mice which injected tachyzoite levels $1 \times 10^{3}$ and $1 \times 10^{4}$, and the incidence of abortion approximately $2-4$ days post injection. $100 \%$ of mice that were injected with tachyzoites $1 \times 10^{1}$ and $1 \times 10^{2}$ have labor at term. Physical anomaly was found in baby mice from mice that were injected with tachyzoite $1 \times 10^{2}$. Conclusion: There is a significant correlation between the concentrations of Toxoplasma gondii tachyzoite with anti-toxoplasma IgG-IgM antibody levels, 
and there is a significant relationship between the concentrations of tachyzoite with abortion.

\section{Keywords}

Toxoplasma gondii Tachyzoite, Anti-Toxoplasma IgG-IgM Antibody Levels, Pregnancy, Abortion, Labor

\section{Introduction}

Toxoplasma gondii ( $T$. gondii) is an obligate intracellular protozoan. There are three forms of $T$. gondii, they are tachyzoite (proliferative forms), cysts (containing bradizoit), and oocysts (containing sporozoite) [1] [2] [3] [4]. T. gondii consists of three types (type I, II and III) and two types from recombination (types IV and V) and has a different pathogenicity. Nowadays, there are at least more than 120 genetic markers that have been developed and used for the determination of T gondii type [5] [6]. Toxoplasmosis is a zoonotic disease caused by $T$. gondii [4]. Toxplasmosis is an important zoonotic disease caused by protozoan parasite $T$. gondii. The disease affects one-third of the total world population [7] [8]. In the world, T. gondii is one of the most common causes of abortion caused by parasite [9]. Limited data is available on the prevalence of T. gondii infections in Indonesia. Gandahusada, (1991) reported incidence of seroprevalence in Indonesia was around 2\% - 63\% [10]. In the field of obstetrics, toxoplasmosis becomes important because can cause bad pregnancy outcomes, such as abortion [11] [12], fetal death [13], hydrcephalus [14] [15] [16] and retinochoroiditis [17] [18] [19]. Humoral immune response associated with a form of active extracellular and invasive tachyzoite in the circulation system. Antibodies IgG and IgM play as the main role in the circulatory system, and IgA plays more dominant in the mucosal surface [20] [21] [22] [23] [24]. This study will prove the relationship between the number of $T$. gondii tachyzoite, with elevated antitoxoplasma IgG and IgM antibody levels in pregnant mice, and pregnancy outcomes.

\section{Materials and Method}

Experimental procedures carried out in Molecular Biology and Immunology Laboratory, Faculty of Medicine, Hasanuddin University, Makassar, Indonesia. This research use adult female mice strain Balb/c according to inclusive criteria (12 - 14 weeks old, BW 25 - 30 gram, no physical deformity). Exclusive criteria are non-active mice. Animal study determined based on the research guidelines for evaluating the safety and efficacy of herbal medicines in accordance with WHO standards. The mice had adaptation for one week, in the laboratory (in a standardized cage) with room temperature $\left(25^{\circ} \mathrm{C} \pm 2^{\circ} \mathrm{C}\right)$, dark and light cycles $(12 / 12 \mathrm{~h})$, fed and watered ad libitum. The conceiving process is combining every two female mice and one adult male mouse in one cage. Mice is pro- 
nounced pregnant if plug sign is found, which is mucous plug shows in introitus vagina, redder colour and thicker vagina compared to before mated. The time of pregnancy was decided by the as zero day finding of plug sign. The amount of sampe is decided of 8 mice because this is a preliminary research. The pregnant mice was divided into 4 groups (K1, K2, K3, K4), each group consisting of two mice. Tachyzoite of pathogen Toxoplasma gondii strains, injected intraperitoneally into mice 1 day after pregnant. Group 1 (K1) injected with tachyzoite $1 \times$ $10^{1}$, group $2(\mathrm{~K} 2)$ injected with tachyzoite $1 \times 10^{2}$, group $3(\mathrm{~K} 3)$ injected with tachyzoite $1 \times 10^{3}$, and group 4 (K4) injected with tachyzoite $1 \times 10^{4}$. Blood samples were taken from the mice of $0.1-0.2 \mathrm{cc}$ serially. The first blood was taken 1 hour before injected with tachyzoite, further blood samples were taken 24 hours, 48 hours, 72 hours, 14 days, and 21 days after injection. The blood was collected and stored in a refrigerator (freezer) at a temperature of $-20^{\circ} \mathrm{C}$. After the mice were injected with tachyzoite, they are assessed every day to observe their body weight, vaginal bleeding, and labor.

\subsection{Toxoplasma gondii Tachyzoite}

Toxoplasma gondii tachyzoite used in this study is a strain of the pathogen RH strain. Tachyzoite suspension was stored at $-20^{\circ} \mathrm{C}$. Tachyzoite concentration used was $1 \times 10^{1}, 1 \times 10^{2}, 1 \times 10^{3}$, and $1 \times 10^{4}$.

\subsection{The Examination Procedures of Anti-Toxoplasma IgG-IgM Antibody Level}

Blood samples examined collectively in Molecular Biology and Immunology Laboratory, Faculty of Medicine, University of Hasanuddin Makassar, Indonesia. Measurement of anti-toxoplasma IgM antibody levels using qualitative mouse IgM antibody (TP-IgM) ELISA KIT. Cat No: MBS9310461. Measurement of anti-toxoplasma IgG antibody levels using qualitative mouse IgG antibody (TP-IgG) ELISA KIT. Cat No: MBS109093. Mechanical antibodies are in accordance with procedures which have been determined in a catalog ELISA Kit.

\section{Results}

Anti-toxoplasma IgG antibody levels before and after injection of $T$. gondii tachyzoite. The sample groups $(\mathrm{K} 1, \mathrm{~K} 2, \mathrm{~K} 3, \mathrm{~K} 4)$ were injected respectively with tachyzoite $1 \times 10^{1}, 1 \times 10^{2}, 1 \times 10^{3}, 1 \times 10^{4}$. Anti-toxolasma IgG antibody level was examined serially ( $2 \mathrm{hr}$ before injection, $24 \mathrm{hr}$ post injection, 48 post injection, $72 \mathrm{hr}$ post injection, 14 days post injection, and 21 days post injection). Anti-toxolasma IgG antibody level was detected positively 72 hours post injection, with cut off point of $0.292 \pm 0.037$ (Table 1, Figure 1).

Anti-toxoplasma IgM antibody levels before and after injection of $T$. gondii tachyzoite. The sample groups (K1, K2, K3, K4) were injected respectively with tachyzoite $1 \times 10^{1}, 1 \times 10^{2}, 1 \times 10^{3}, 1 \times 10^{4}$. Anti-toxolasma IgG antibody level was examined serially ( $2 \mathrm{hr}$ before injection, $24 \mathrm{hr}$ post injection, $48 \mathrm{hr}$ post injection, $72 \mathrm{hr}$ post injection, 14 days post injection, and 21 days post injection). 
Anti-toxolasma IgM antibody level was detected positively 24 hours post injection, with cut off point of $0.332 \pm 0.0045$ (Table 2, Figure 2).

Mice that injected with $1 \times 10^{1}$ and $1 \times 10^{2}$ all samples gave birth at term (100\%), while mice that injected with $1 \times 10^{3}$ and $1 \times 10^{4}$ tachyzoite all samples undergo abortion (found vaginal bleeding) about 2 - 4 days post injection. The sample group which injected with $1 \times 10^{1}$ tachyzoite gave birth to seven and nine neonatal mice and none of them are found with physical anomaly. Anyhow, the sample group which injected with $1 \times 10^{2}$ tachyzoite gave birth to five and seven neonatal mice. A physical anomaly was found; that is crooked tail bone in one neonatal mice from each both sample (Table 3 ).

Table 1. Anti-toxoplasma IgG antibody levels before and after injection of $T$. gondii tachyzoite.

\begin{tabular}{|c|c|c|c|c|c|}
\hline \multirow{2}{*}{$\begin{array}{l}\text { Time When } \\
\text { Antibody Level } \\
\text { Is Identified }\end{array}$} & \multicolumn{4}{|c|}{$\begin{array}{l}\text { The Concentration of Tachyzoite } \\
\text { Anti-Toxoplasma IgG Antibody Level }\end{array}$} & \multirow{2}{*}{ Cut Off } \\
\hline & $\mathrm{K} 1\left(1 \times 10^{1}\right)$ & $\mathrm{K} 2\left(1 \times 10^{2}\right)$ & $\mathrm{K} 3\left(1 \times 10^{3}\right)$ & $\mathrm{K} 4\left(1 \times 10^{4}\right)$ & \\
\hline $\begin{array}{l}2 \text { hours before } \\
\text { injection }\end{array}$ & $0.121 \pm 0.007$ & $0.131 \pm 0.007$ & $0.218 \pm 0.008$ & $0.230 \pm 0.003$ & \\
\hline $\begin{array}{l}24 \text { hours post } \\
\text { injection }\end{array}$ & $0.120 \pm 0.005$ & $0.130 \pm 0.009$ & $0.234 \pm 0.011$ & $0.226 \pm 0.003$ & \\
\hline $\begin{array}{l}48 \text { hours post } \\
\text { injection }\end{array}$ & $0.126 \pm 0.003$ & $0.124 \pm 0.007$ & $0.249 \pm 0.006$ & $0.229 \pm 0.006$ & \\
\hline $\begin{array}{l}72 \text { hours post } \\
\text { injection }\end{array}$ & $0.327 \pm 0.033$ & $0.368 \pm 0.035$ & $0.387 \pm 0.021$ & $0.377 \pm 0.019$ & $0.292 \pm 0.037$ \\
\hline $\begin{array}{l}14 \text { days post } \\
\text { injection }\end{array}$ & $0.665 \pm 0.011$ & $0.699 \pm 0.017$ & $0.787 \pm 0.028$ & $0.829 \pm 0.071$ & \\
\hline $\begin{array}{l}21 \text { days post } \\
\text { injection }\end{array}$ & $1.246 \pm 0.012$ & $1.302 \pm 0.060$ & $1.374 \pm 0.020$ & $1.488 \pm 0.014$ & \\
\hline
\end{tabular}

Table 2. Anti-toxoplasma IgM antibody level before and after injection of $T$. gondii tachyzoite.

\begin{tabular}{|c|c|c|c|c|c|}
\hline \multirow{2}{*}{$\begin{array}{l}\text { Time When } \\
\text { Antibody Level } \\
\text { Is Identified }\end{array}$} & \multicolumn{4}{|c|}{$\begin{array}{l}\text { The Concentration of Tachyzoite } \\
\text { Anti-Toxoplasma IgM Antibody Level }\end{array}$} & \multirow{2}{*}{ Cut Off } \\
\hline & $1 \times 10^{1}$ & $1 \times 10^{2}$ & $1 \times 10^{3}$ & $1 \times 10^{4}$ & \\
\hline $\begin{array}{l}2 \text { hours before } \\
\text { injection }\end{array}$ & $0.166 \pm 0.008$ & $0.207 \pm 0.003$ & $0.179 \pm 0.015$ & $0.185 \pm 0.009$ & \\
\hline $\begin{array}{l}24 \text { hours post } \\
\text { injection }\end{array}$ & $0.556 \pm 0.022$ & $0.554 \pm 0.021$ & $0.619 \pm 0.030$ & $0.548 \pm 0.009$ & $0.332 \pm 0.045$ \\
\hline $\begin{array}{l}48 \text { hours post } \\
\text { injection }\end{array}$ & $0.928 \pm 0.019$ & $0.959 \pm 0.029$ & $1.040 \pm 0.037$ & $0.889 \pm 0.012$ & \\
\hline $\begin{array}{l}72 \text { hours post } \\
\text { injection }\end{array}$ & $1.292 \pm 0.033$ & $1.326 \pm 0.007$ & $1.427 \pm 0.017$ & $1.480 \pm 0.013$ & \\
\hline $\begin{array}{l}14 \text { days post } \\
\text { injection }\end{array}$ & $1.312 \pm 0.022$ & $1.331 \pm 0.017$ & $1.466 \pm 0.030$ & $1.477 \pm 0.008$ & \\
\hline $\begin{array}{l}21 \text { days post } \\
\text { injection }\end{array}$ & $1.322 \pm 0.022$ & $1.354 \pm 0.008$ & $1.466 \pm 0.088$ & $1.495 \pm 0.006$ & \\
\hline
\end{tabular}


Table 3. The relationship between $T$. gondii tachyzoite doses with pregnancy outcomes.

\begin{tabular}{ccc}
\hline \multirow{2}{*}{\begin{tabular}{c} 
The $\begin{array}{c}\text { Concentration of } \\
\text { Tachyzoite }\end{array}$ \\
\cline { 2 - 3 }
\end{tabular}} & \multicolumn{2}{c}{ Outcome Pregnancy } \\
\hline $1 \times 10^{1}$ & Abortion (\%) & 100 \\
$1 \times 10^{2}$ & 100 & \\
$1 \times 10^{3}$ & 100 & \\
$1 \times 10^{4}$ & 100 \\
\hline
\end{tabular}

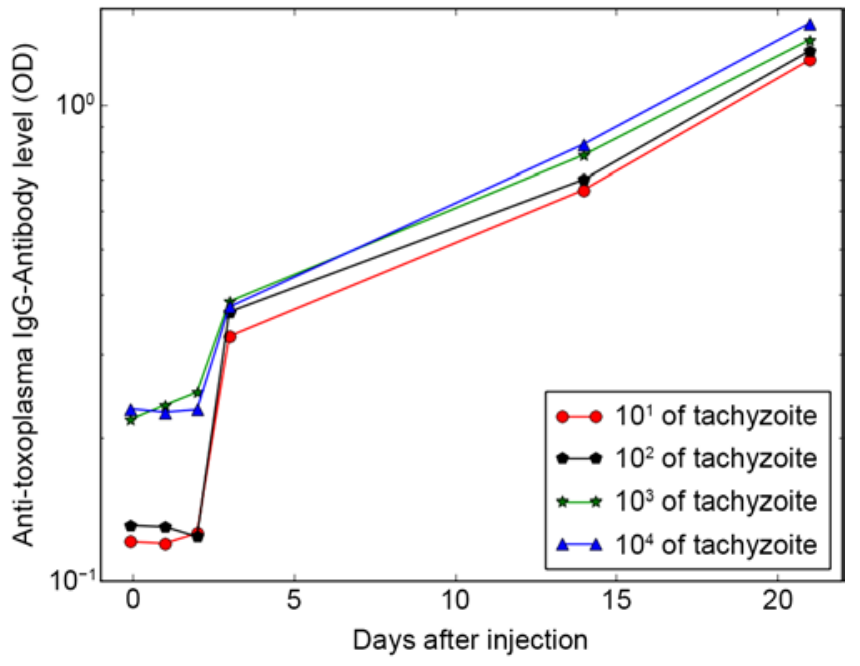

Figure 1. Anti-toxoplasma IgG antibody levels before and after injection of tachyzoite. Anti-toxoplasma IgG antibody levels increased significantly after 72 hours post injection tachyzoite. The highest levels of anti-toxoplasma IgG antibodies in mice injected with $1 \times$ $10^{4}$ tachyzoite.

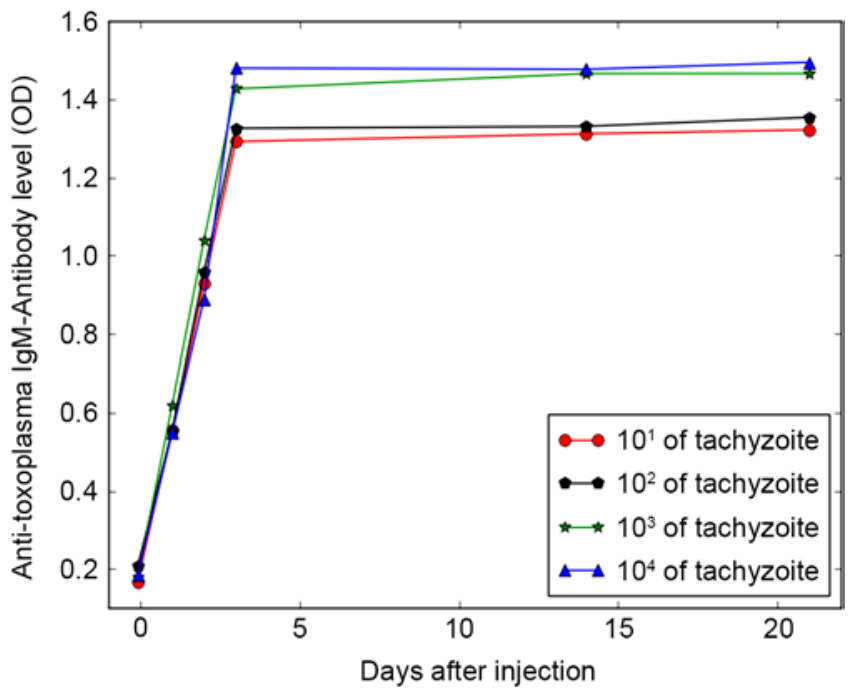

Figure 2. Anti-toxoplasma IgM antibody levels before and after injection of tachyzoites. Anti-toxoplasma IgM antibody levels increased sharply after 24 hours post injection tachyzoite. After 72 hours after injection, anti-toxoplasma IgM antibody levels increased not significantly. The highest levels of anti-toxoplasma IgM antibodies in mice injected with $1 \times 10^{4}$ tachyzoite. 


\section{Discussion}

In this study, we analyzed the outcomes of pregnancy, and the anti-toxoplasma IgG-IgM antibody levels, with doses of injected toxoplasma tachyzoites in early pregnant mice. In this study, we found that the amount/concentration of tachyzoites that infect mice in early pregnancy is associated with the outcomes. This study concluded abortion occurred in the group of injected mice with dose $1 \times$ $10^{3}$ and $1 \times 10^{4}$, and abortion occurs about 2 - 4 days after intraperitoneal injection, while a group of tachyzoites injected doses of $1 \times 10^{1}$ and $1 \times 10^{2}$ are all born at term. Castano, et al., (2014) reported that the incidence of abortion around $91.6 \%$ and occurred between day 7 and 11 after the 2000 sporula oocytes given orally in sheep. The incidence of abortion around $58.3 \%$, and occurred between day 9 and day 11 post-administration of 500 sporula oocytes [25].

In this study, the IgG antibody level increase significantly 3 days post tachyzoite injection and keep increasing until day 21 . Mean while, the IgM antibody level increase significantly 1 day post tachyzoite injection and keep increasing until day 21. De Carlo, et al., (2008) reported that the IgM antibody level increase at day 5 - 7 and maximized until 1 - 2 months after acute infection, and decreased faster than IgG antibody level. However, in some cases, the IgM antibody level persisted after acute infection of toxoplasma. The IgG antibody level usually detected in $1-2$ weeks post injection, and peaked at 12 weeks to 6 months post infection and prolonged for years and usually persist live long [26].

Several animal studies reported that abortion can occur due to acute infection of $T$. gondii. Abortion occurs because of damage to the products of conception due to parasite replication in the placenta or fetus [27] [28]. The incidence of thrombosis and infarction in the placenta also can occur on the event that have nothing to do with the replication of the parasite. Castario, et al., (2014) reported thrombosis and infarction occurs in the placenta and sheep fetus without antigen or parasites replication, and also reported elevated levels of interferongamma (IFN- $\gamma$ ) was significantly in abortion group than the control group [25].

In this study, the physical anomaly was a crooked tail bone found in neonatal mice from the group which injected with tachyzoite $1 \times 10^{2}$. The cause of this anomaly is unclear, since infection of $T$. gondii in pregnancy usually cause congenital defect such a hydrocephalus and retino choroiditis [29] [30].

\section{Conclusion}

Anti-toxoplasma IgM antibody levels increased significantly after 24 hours of injection of $T$. gondii tachyzoites in all dose groups, and remained high until day 21, whereas anti-toxoplasma IgG antibody levels increased significantly after 72 hours post injection tachyzoites and remained elevated through day 21 . The incidence of abortion is $100 \%$ in the group of mice with injected tachyzoites doses of $1 \times 10^{3}$ and $1 \times 10^{4}$, and abortion occurs about $2-4$ days post-injection. Mice were injected tachyzoites $1 \times 10^{1}$ and $1 \times 10^{2}$ have labor at term $100 \%$. Physical anomaly was found in neonatal mice from mice that were injected with tachyzoite $1 \times 10^{2}$. There is a significant correlation between the concentrations of 
Toxoplasma gondii tachyzoite with anti-toxoplasma IgG-IgM antibody levels, and there is a significant relationship between the concentrations of tachyzoite with abortion.

\section{Acknowledgements}

Thanks to laboratory staff from Molecular Biology and Immunology Laboratory, Faculty of Medicine, Hasanuddin University, Makassar for helping this experimental study.

\section{Conflicts of Interest}

The authors declare no conflict of interest.

\section{References}

[1] Saeij, J.P., Boyle, J.P. and Boothroyd, J.C. (2005) Differences among the Three Major Strains of Toxoplasma gondii and Their Specific Interactions with The Infected Host. Trends Parasitol, 10, 476-481. https://doi.org/10.1016/j.pt.2005.08.001

[2] Dardé, M.L. (2008) Toxoplasma gondii, "New" Genotypes and Virulence. Parasite, 13, 366-371. https://doi.org/10.1051/parasite/2008153366

[3] Skariah, S., McIntyre, M.K. and Mordue, D.G. (2010) Toxoplasma gondii: Determinants of Tachyzoite to Bradyzoid Conversion. Parasitology Research, 107, 253 260. https://doi.org/10.1007/s00436-010-1899-6

[4] Wang, L., Chen, H., Liu, D., Huo, X., Gao, J., Song, X., et al. (2013) Genotypes and Mouse Virulence of Toxoplasma gondii Isolates from Animals and Humans in China. PLoS One, 8, e53483. http://dx.doi.org/10.1371/journal.pone.0053483

[5] Herrmann, D.C., Bärwald, A., Maksimov, A., Pantchev, N. and Vrhovec, M.G. (2012) Toxoplasma gondii Sexual Cross in a Single Naturally Infected feline Host: Generation of Highly Mouse-Virulent and Avirulent Clones, Genotypically Different from Clonal Types I, II and III. Veterinary Researsh, 43, 39. https://doi.org/10.1186/1297-9716-43-39

[6] Sibley, L.D. and Howe, D.K. (1996) Genetic Basis of Pathogenicity in Toxoplasmosis. In: Gross, U., Ed., Toxoplasma gondii, Springer-Verlag, Berlin, 3-15. https://doi.org/10.1007/978-3-642-51014-4_1

[7] Sibley, L.D., Mordue, D.G., Robben, P.M. and Howe, D.K. (2002) Genetic Approaches to Studying Virulence and Pathogenesis in Toxoplasma gondii. Philosophical Transactions of the Royal Society B: Biological Sciences, 357, 81-88. https://doi.org/10.1098/rstb.2001.1017

[8] Mittal, V. and Ichhpujani, R.L. (2011) Toxoplasmosis-An Update. Tropical Parasitology, 1, 9-14. https://doi.org/10.4103/2229-5070.72109

[9] Shaapan, R.M. (2016) The Common Zoonotic Protozoal Diseases Causing Abortion. Journal of Parasitic Diseases, 40, 1116-1129.

https://doi.org/10.1007/s12639-015-0661-5

[10] Gandahusada, S. (1991) Study on the Prevalence of Toxolasmosis in Indonesia: A Review. Southeast Asian Journal of Tropical Medicine and Public Health, 22, 93-98.

[11] Li, X.L., Wei, H.X., Zhang, H., Peng, H.J. and Lindsay, D.S. (2014) A Meta Analysis on Risks of Adverse Pregnancy Outcomes in Toxoplasma gondii Infection. PLoS One, 9, e97775. http://dx.doi.org/10.1371/journal.pone.0097775 
[12] Tammam, A.E., Haridy, M.A.M., Abdellah, A.H., et al. (2013) Seroepidemiology of Toxoplasma gondii Infection in Women with First Trimester Spontaneous Miscarriage in Qena Governorate, Egypt. Journal of Clinical and Diagnostic Research, 7, 2870-2873.

[13] Esquivel, C.A., Vega, S.J.P., Jaquez, M.S., Anguiano, L.F.S., Tinoco, J.H. and Sanchez, E.R. (2015) Stillbirth History and Toxoplasma gondii Infection in Women Attending Public Health Centers in a Northern Mexican City. European Journal of Microbiology and Immunology, 5, 164-171. https://doi.org/10.1556/1886.2015.00009

[14] Stahl, W. and Kaneda, Y. (1997) Pathogenesis of Murine Toxoplasmic Hydrocephalus. Parasitology, 114, 219-229. https://doi.org/10.1017/S0031182096008505

[15] Hutson, S.L., Wheeler, K.M., McLone, D., Frim, D., Penn, R., Swischer, C.N., et al. (2015) Patterns of Hydrocephalus Caused by Congenital Toxoplasma gondii Infection Associate with Parasite Genetics. Clinical Infectious Diseases, 61, 1831 1834. https://doi.org/10.1093/cid/civ720

[16] Stajner, T., Bobic, B., Klun, I., Nikolic, A., Srbljanovic, J., Uzelac, A., et al. (2016) Prenatal and Early Postnatal Diagnosis of Congenital Toxoplasmosis in a Setting with No Systematic Screening in Pregnancy. Medicine, 95, e2979. https://doi.org/10.1097/MD.0000000000002979

[17] Furtado, J.M., Bharadwaj, A.S., Chipps, T.J., Pan, Y., Ashlander, L.M. and Smith, J.R. (2012) Toxoplasma gondii Tachyzoites Cross Retinal Endothelium Assisted by Intercellular Adhesion Molecule-1 in Vitro. Immunology \& Cell Biology, 90, 912 915. https://doi.org/10.1038/icb.2012.21

[18] Carneiro, A.C., Machado, A.S., Béla, S.R., Costa, J.G., Andrade, G.M., Vasconcelos-Santos D.V., et al. (2016) Cytokine Signatures Associated with Early Onset, Active Lesions and Late Cicatricial Events of Retinochoroidal Commitment in Infants with Congenital Toxoplasmosis. Journal of Infectious Diseases, 213, 1962-1970. https://doi.org/10.1093/infdis/jiw041

[19] Park, O.H. and Nam, H.W. (2013) Clinical Features and Treatment of Ocular Toxoplasmosis. Korean Journal of Parasitology, 51,393-399.

https://doi.org/10.3347/kjp.2013.51.4.393

[20] Gelaye W., Kebede T., Hailu A. (2015) High Prevalence of Anti-Toxoplasma Antibodies and Absence of Toxoplasma gondii Infection Risk Factors among Pregnant Women Attending Routine Antenatal Care in Two Hospitals of Addis Ababa, Ethiopia. International Journal of Infectious Diseases, 34, 41-45. https://doi.org/10.1016/j.ijid.2015.03.005

[21] Siddiqui, N., Shujatullah, F., Kan, H.M., Rabbani, T. and Khan, P.A. (2014) IgG Avidity Antibodies against Toxoplasma Gondi in High Risk Females of Reproductive Age Group in India. Korean Journal of Parasitology, 52, 487-491. https://doi.org/10.3347/kjp.2014.52.5.487

[22] Satti, A.B., Suliman, H. and Suad, B.M. (2011) Serological and Molecular Diagnosis of Toxoplasmosis in Pregnant Women in Omdurman, Khartoum State. Sudan Medical Laboratory Journal, 1, 60-73.

[23] Duphont, C.D., Christian, D.A. and Hunter, C.A. (2012) Immune Response and Immunopathology during Toxoplasmosis. Seminars in Immunopathology, 34, 793813. https://doi.org/10.1007/s00281-012-0339-3

[24] Chardes, T., Isabelle, B., Mevelec, M.N., Dubremetz, J.F. and Bout, D. (1990) Antibody Responses to Toxoplasma gondii in Sera, Intestinal Secretions, and Milk from Orally Infected Mice and Characterization of Target Antigens. Infection and Immunity, 58, 1240-1246. 
[25] Castano, P., Fuertes, M., Ferre, I., Fernandez, M., Fereras, M.D., Gonzalo, J.M., et al. (2014) Placental Thrombosis in Acut Phase Abortions during Experimental Toxoplasma gondii Infection in Sheep. Veterinary Research, 45, 9. https://doi.org/10.1186/1297-9716-45-9

[26] Di Carlo, P., Romano, A., Schimmenti, M.G., Mazzola, A. and Titone, L. (2008) Materno-fetal Toxoplasma gondii Infection: Critical Review of Available Diagnostic Methods. Le Infezioni in Medicina, 16, 28-32. https://doi.org/10.1016/j.vetpar.2011.06.023

[27] Castaño, P., Fuertes, M., Cerrillo, J.P., Ferre, I., Fernández, M., Ferreras, M.C., et al. (2016) Experimental Ovine Toxoplasmosis: Influence of the Gestational Stage on the Clinical Course, Lesion Development and Parasite Distribution. Veterinary Research, 47, 43. https://doi.org/10.1186/s13567-016-0327-Z

[28] de Moraes, E.P., da Costa, M.M., Dantas, A.F., da Silva, J.C. and Mota, R.A, (2011). Toxoplasma gondii Diagnosis in Ovine Aborted Fetuses and Stillborns in the State of Pernambuco, Brazil. Veterinary Parasitology, 183, 152-155. https://doi.org/10.1016/j.vetpar.2011.06.023

[29] Jamieson, S.E., de Roubaix, L.A., Cortina-Borja, M., Tan, H.K., Mui, E.J., Cordell, H.J., et al. (2008) Genetic and Epigenetic Factors at COL2A1 and ABCA4 Influence Clinical Outcome in Congenital Toxoplasmosis. PLoS One, 3, e2285. https://doi.org/10.1371/journal.pone.0002285

[30] Hutson, S.L., Wheeler, K.M., McLone, D., Frim, D., et al. (2015) Patterns of Hydrocephalus Caused by Congenital Toxoplasma gondii Infection Associate with Parasite Genetics. Clinical Infectious Diseases, 61, 1831-1834. https://doi.org/10.1093/cid/civ720

Submit or recommend next manuscript to SCIRP and we will provide best service for you:

Accepting pre-submission inquiries through Email, Facebook, LinkedIn, Twitter, etc. A wide selection of journals (inclusive of 9 subjects, more than 200 journals) Providing 24-hour high-quality service User-friendly online submission system Fair and swift peer-review system Efficient typesetting and proofreading procedure Display of the result of downloads and visits, as well as the number of cited articles Maximum dissemination of your research work

Submit your manuscript at: http://papersubmission.scirp.org/ Or contact ojog@scirp.org 